\title{
Description of Photuris fulvipes (Blanchard) immatures (Coleoptera, Lampyridae, Photurinae) and bionomic aspects under laboratory conditions
}

\author{
Simone Policena Rosa
}

${ }^{1}$ Museu de Zoologia da Universidade de São Paulo, Avenida Nazaré 481, 04263-000 São Paulo-SP, Brazil. simonepr@usp.br

\begin{abstract}
Description of Photuris fulvipes (Blanchard) immatures (Coleoptera, Lampyridae, Photurinae) and bionomic aspects under laboratory conditions. Larvae and pupae of the cryptic firefly Photuris fulvipes (Blanchard,1837) are described. They were reared to adult stage from eggs laid by a female collected in São Luiz do Paraitinga, São Paulo, Brazil. Additionally, adult diagnosis and some bionomic data observed in the laboratory are presented. The bionomical and morphological characteristics of $P$. fulvipes were compared to other unidentified species of the genus and to Bycellonycha sp. from literature. At moment, the data are insufficient to propose a diagnosis for the species, but some characteristics appear to define species group or, at least, they may have generic value.
\end{abstract}

KEYWORDS. Adult; firefly; larvae; egg; pupae.

\begin{abstract}
RESUMO. Descrição dos imaturos de Photuris fulvipes (Blanchard) (Coleoptera, Lampyridae, Photurinae) e aspectos bionômicos sob condições de laboratório. Larva e pupa de Photuris fulvipes (Blanchard, 1837), criadas a partir de ovos de uma fêmea coletada em São Luiz do Paraitinga, São Paulo, são descritas. São apresentados uma diagnose do adulto e alguns dados bionômicos observados durante a criação em laboratório. Esses dados e a morfologia dos imaturos foram comparados aos de outras espécies não identificadas do gênero e a Bycellonycha sp., descritos na literatura. Nesse momento, os dados são insuficientes para propor uma diagnose para a espécie, mas algumas características parecem ser importantes para definir grupos de espécies ou, pelo menos, para diagnosticar o gênero.
\end{abstract}

PALAVRAS-CHAVE. Adulto; lampirídeo; larva; ovo; pupa.

The genus Photuris LeConte, 1851 comprises common fireflies that occur throughout Neotropical and Nearctic Region. The morphology and behavior of some Photuris species have been extensively studied in North America and Mexico (McDermott 1967; Lloyd 1984; Buschman 1984; Zaragoza 1995). Nevertheless, despite the effort of systematists, the taxonomy of the genus remains a puzzle and the species identification, mainly for the South American species, is very difficult. Sixteen species have been described from Brazil (Blackwelder, 1944), a few of them were recently revised or had its behavior and bionomic aspects studied (Costa et al. 1988; Viviani 2001).

Most adult Photuris fireflies are morphologically cryptic with sexual isolation maintained by the differences in the flash communication systems and probably by geographical distribution and seasonal occurrence of adults (Barber 1951; Buschman 1984). The differences in the life cycle and morphological characteristics of larvae of North American Photuris were investigated by Buschman (1984), who pointed out that some differences appear to be restricted to species or, at least, to species groups. These results highlight the importance of additional morphological and biological studies of immature fireflies.

The purpose of this study is to present a morphological description and developmental data of the Photuris fulvipes (Blanchard, 1837) immatures, which will improve the knowledge of Brazilian fireflies and could help define more accurately the species of the genus Photuris. Furthermore, some bionomic aspects observed during the larval rearing are reported and the diagnostic characteristics of the adult are presented. The immatures were obtained from eggs laid by a female collected in São Luiz do Paraitinga, São Paulo, Brazil. They were reared until adult stage in laboratory and the complete life cycle was observed and is described herein. Moults, fixed larvae, pupae and adults are deposited in the dry and humid collections of the Museu de Zoologia da Universidade de São Paulo.

\section{MATERIALAND METHODS}

The eggs were laid by a female collected at night in a pasture at São Pedro ranch, a privately-owned property in the rural area of São Luiz do Paraitinga, SP $\left(23^{\circ} 13^{\prime} 23^{\prime \prime}\right.$ S, 45 $45^{\circ} 18^{\prime}$ $38^{\prime \prime} \mathrm{W}$ ). In the field, the female were placed in a glass container with damp soft paper on which fifty-nine eggs were observed after some 12 hours.

In the laboratory, these eggs were transferred to damp filter paper on fine sand layer inside an acrylic jar and kept at 25$30^{\circ} \mathrm{C}$. They were observed and the sand layer was moistened daily. Fifty-five larvae hatched from these eggs, which were then held individually in acrylic jars containing damp fine sand. These larvae were fed twice a week with live termite nymphs in the two first instars, and with adult termites in the remaining instars. Moulting time was recorded when the exuviae was observed for the first time.

Larvae of each instar and pupae were killed in boiling water. These samples, moults and adults were fixed in $70 \%$ alcohol. 

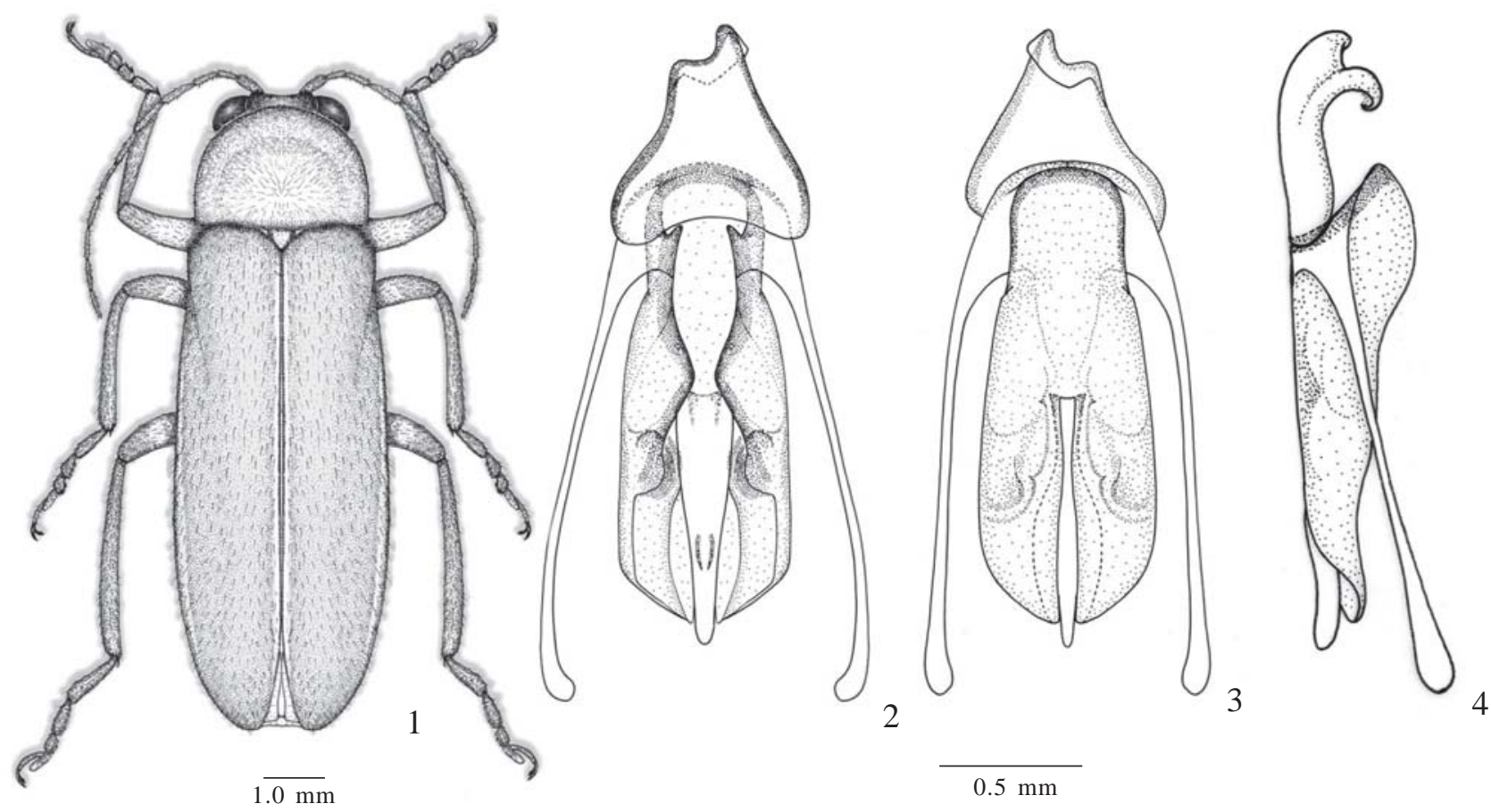

Figs. 1-4. Photuris fulvipes (Blanchard, 1837). 1, male, habitus; 2-4, aedeagus (ventral, dorsal, lateral).

Drawings were made with the aid of a camera lucida connected to a stereomicroscope. The morphological terminology was used according to Costa et al. (1988) and Lawrence (1991).

\section{RESULTS ANDDISCUSSION}

Bionomic data. The larvae hatched 19 days after oviposition. The total post-embrionary period including six or seven larval instars and a pupae stage had an average duration of 282 days (Table 1). Fourteen larvae reached the adult stage over six instars and one over seven instars. As can be seen in Table 1, the duration of each stage varied greatly. This variation may be due to the phenotypic plasticity and also to failure in the observation. The latter may have been an important factor mainly as from the third larval instar, when the larvae began to hide in a chamber and, therefore, it was no longer possible to fix the exact molting time.

The larvae from the third to the last instar excavated the substrate and constructed shallow and spherical chambers that could be externally distinguished on the sand by the concave, circular and thin ceiling. Such molting chambers have been reported and their forms appear to be characteristic to some Photuris species (Buschman 1984). During the present study, it was observed that in the third instar approximately half of larvae constructed moulting chambers in which they stayed inactive for 5, 9 or 17 days before moulting and while they were pupating. In the remaining instars all larvae constructed chambers, in which they stayed from 5 to 44 days before molting and during pupation. The form of these chambers was similar to that illustrated by Buschman (1984) and constructed by a larvae referred by this author as Photuris "A". A few larva did not moult after remaining some time in the chamber.

The larvae glowed only during the inactive period before pupation. Later, they emitted weak yellowish luminescence through a pair of small spots on the $8^{\text {th }}$ sterna. In the pupae these luminescent spots could be more distinctly seen dorsally and ventrally in the $8^{\text {th }}$ segment. The photogenic vesicles are not visible in the fixed larvae and pupae.

\section{Descriptions}

Photuris fulvipes (Blanchard, 1837)

Lampyris fulvipes Blanchard, 1837: 115 (desc.). Type locality: Mexico. Photuris fulvipes; Olivier, 1907: 58 (cat.).

Telephorödes fruticola Motschulsky, 1854: 60 (desc.). Type locality: Guatemala.

Table I. Duration in days of post-embrionary development of Photuris fulvipes (Blanchard, 1837).

\begin{tabular}{llllllllll}
\hline & \multicolumn{8}{c}{ Larva instars } & \\
\cline { 2 - 7 } Stages & $1^{\text {st }}$ & $2^{\text {nd }}$ & $3^{\text {rd }}$ & $4^{\text {th }}$ & $5^{\text {th }}$ & $6^{\text {th }}$ & $7^{\text {th }}$ & Pupa & Total \\
Duration & $19-20$ & $20-27$ & $20-46$ & $35-109$ & $34-99$ & $59-101$ & 84 & $3-11$ & $280-326$ \\
Average & 19.6 & 23.3 & 21.8 & 57.2 & 62.0 & 85.8 & - & 5.3 \\
\hline
\end{tabular}



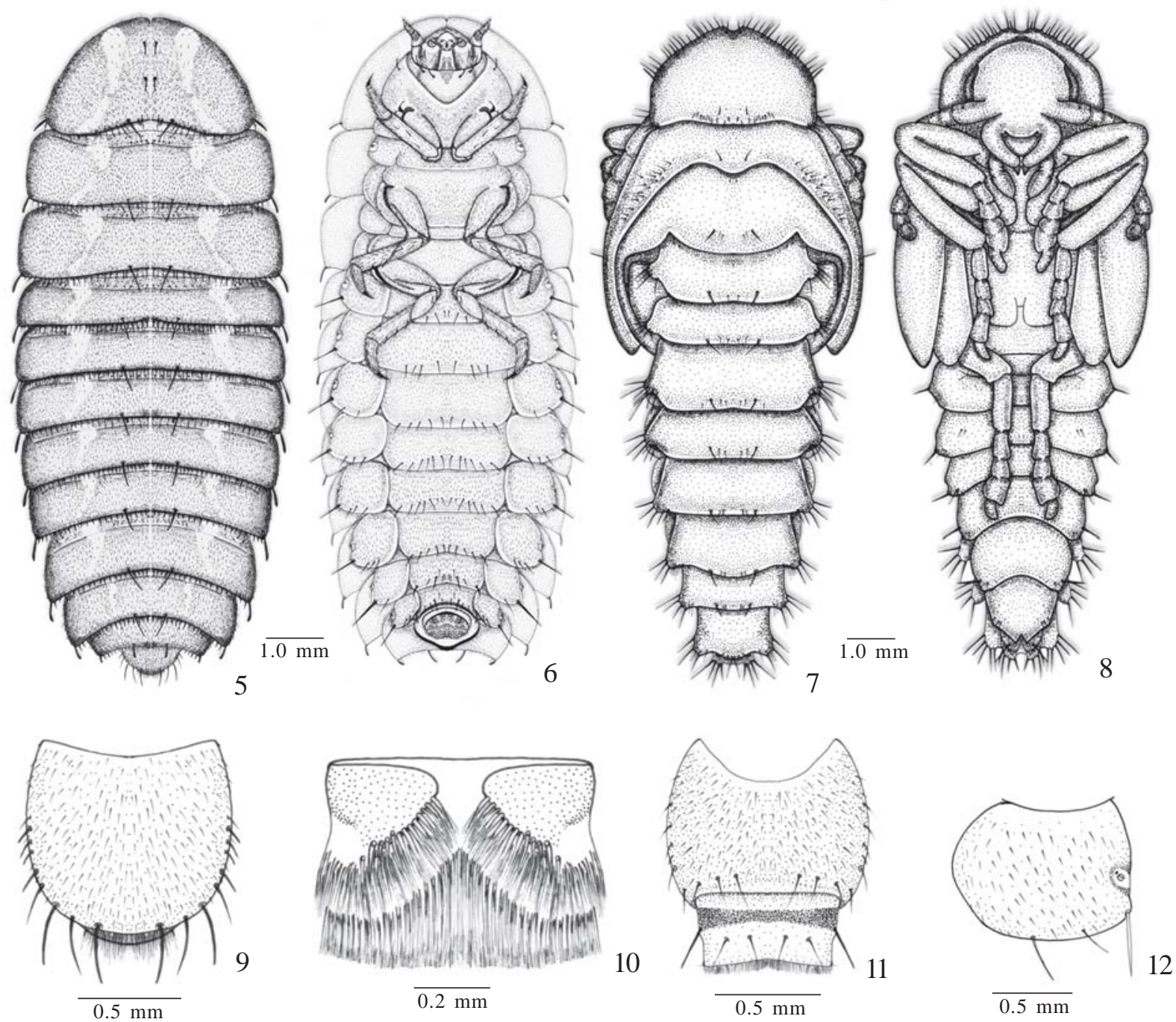

Figs. 5-12. Photuris fulvipes. 5, 6, 9-12, larva, 5, 6, habitus (dorsal, ventral), 9, tergum 9; 10, tergum 10; 11, sterna 9 and 10; 12 , abdominal epipleurum. 7, 8, pupa, habitus (dorsal, ventral).

Photuris fruticola; Olivier, 1886: 235 (key, redesc.); Olivier, 1907 (cat., syn.).

Telephoroïdes occidentalis Motschulsky 1854: 60 (desc.). Type locality: Brazil.

Photuris occidentalis; Olivier, 1886: 235 (syn.).

Telephorö̈des pallida Motschulsky, 1854: 61 (desc.). Type locality: Uruguay.

Photuris pallida; Olivier, 1886: 235 (syn.).

Photuris trivialis Boheman, 1858: 77 (desc.); Olivier, 1886 (syn.).

Adult diagnosis (Fig. 1). Total length 10.0-10.6 mm. Body slender, parallel-sided, covered with fine and short pubescence; pronotum semicircular, slightly convex, finely, sparsely punctate, covering almost entirely the head; elytra densely punctate with strigae indistinct or with 4 weak strigae. Prothorax bright yellow; elytra brown, except for the suture and lateral margins pale-yellow; head, antennae and legs dark brown, except for the femur with $2 / 3$ basal yellow; outer claws bifid in both sexes. Antennae 0.53 of body length. Males have luminescent organs occupying entirely the $5^{\text {th }}, 6^{\text {th }}$ and $7^{\text {th }}$ ventrites; the two first deeply marginate on posterior margin; luminescent organs in females occupying almost entirely the $5^{\text {th }}$ and $6^{\text {th }}$ ventrites, $7^{\text {th }}$ ventrite triangular, sclerotized. Aedeagus (Figs. 2-4). Parameres with basal $1 / 2$ fused together medially at dorsal face, dorsal basal area strongly convex, ventral margin sinuate, abruptly narrowed at basal 1/4; penis articulated with parameres at middle; phallobase ventral.

Flash pattern. During the collection were observed adults emitting two short flashes with an interval of approximately 2 seconds.

Examined material. BRAZIL. São Paulo, São Luiz do Paraitinga, 03.XI.2000, S. P. Rosa \& M. Ladenthin coll.; 8 males, 5 females (reared); 1 male, 1 female (collected).

Taxonomic discussion. Olivier $(1886,1907)$ observed that there are some variations in the body pigmentation of Photuris fulvipes, such as black elytra and bicolored head, that led several authors to describe new species (see above the synonymic list). Despite the apparent geographical disjunction, Olivier (sup. cit.) considered them as variations of a single 


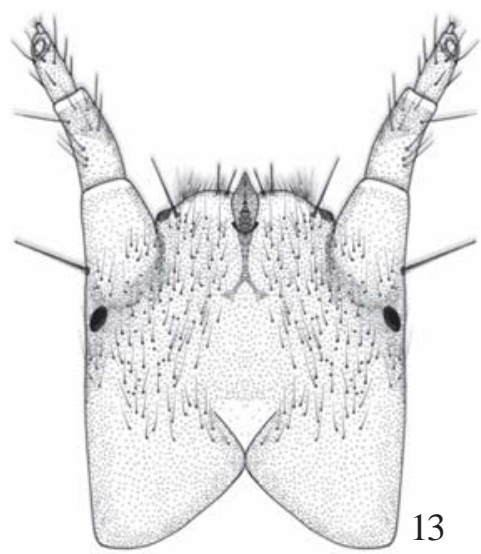

$0 . \overline{2 \mathrm{~mm}}$

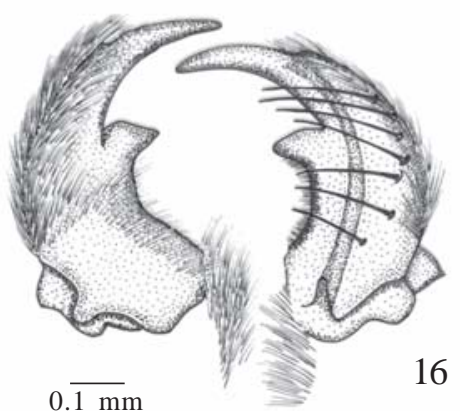

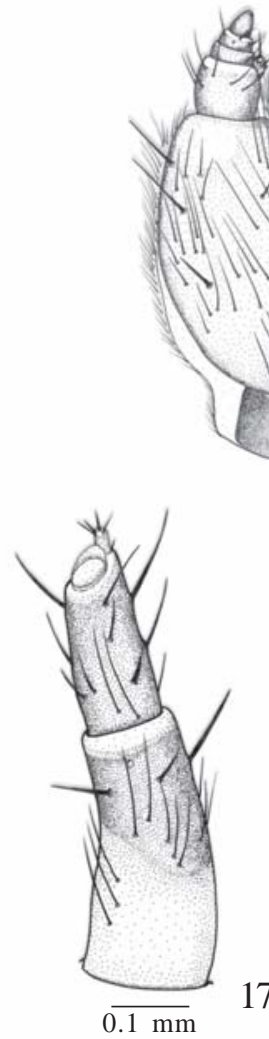

17

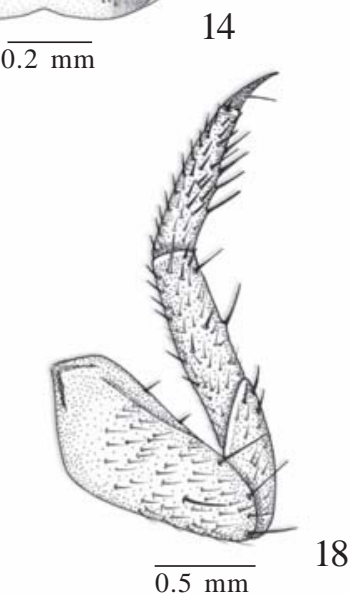

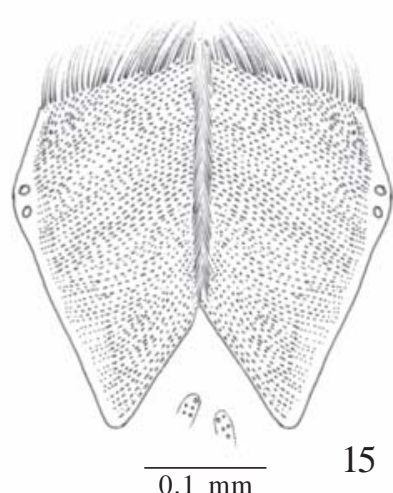

15

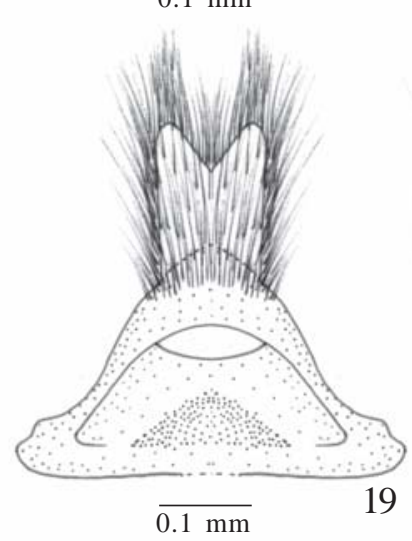

Figs. 13-19. Photuris fulvipes, larva. 13, head (dorsal); 14, hypostoma; 15, epipharynx; 16, mandibles (ventral, dorsal); 17, antennae (dorsal); 18, anterior leg; 19, hypopharynx.

species. However, characteristics more confident which has usually separate fireflies species, as the aedeagus morphology and flash patterns, were not yet compared between the populations of $P$. fulvipes. The specimens reared in this study are similar to the variety "floridana" of $P$. brunnipennis Barber, 1951 from Florida (USA), except for the yellow head of $P$. brunnipennis (McDermott 1967). Males of the latter emit short, single flash. An unidentified species of Photuris from São Paulo state was investigated by Viviani (2001) that observed: "Flying males were found emitting two flash patterns: single flash and bimodulated flashes. The reason for such variation is still unknown". Certainly, our knowledge on the flash patterns of this firefly species is still much incipient and more accurate field studies on them are indispensable for future taxonomic revisions.

Egg. Diameter $1.1 \mathrm{~mm}$; spherical, cream-yellow becoming more transparent before hatching, without microsculptures.

$\mathbf{1}^{\text {st }}$ instar larva. Total length $2.7 \mathrm{~mm}$; differ from the mature larvae by the unpigmented body and by mandibles, which have the inner margin microdentate basally to retinaculum and several elongate and stout spiniform setae on ventral surface.

$6^{\text {th }}$ instar larva (Figs. 5, 6 -19). Total length $12.2 \mathrm{~mm}$. Campodeiform (Figs. 5, 6), dorsoventrally flattened, legs and head concealed under the terga, head prognathous, protractible. Dorsal surface dark-brown with a pair of lateral, elongate and yellowish stains on thoracic and 1-7 abdominal terga, clothed with fine and whitish pubescence; thoracic and 1-8 abdominal terga with a pair of stout elongated setae on midline; epipleura with one subfoliaceous seta on posterior angle. Ventral surface yellow, sparsely pubescent; abdomen with a row of stout setae on posterior margin of sterna and epipleura and a longer stout seta on posterior angle of epipleura.

Head (Fig. 13). Slightly longer than wide, partially retractile into prothorax (Fig. 6); dorsal surface clothed with long, fine and sparse setae, one stemmata situated basally to the antennifer; antennifer large and membranous with a lateral, long and stout seta. Frontal arms distinct only in the base, vshaped; nasale (Figs. 13, 20) latero-anteriorly bisinuate with a strongly sclerotized tooth in the middle. Antennae (Fig. 17) elongate, 3 -segmented, $1^{\text {st }}$ segment partially sclerotized, $2^{\text {nd }}$ segment sclerotized, both with several fine and stout elongate setae; apex of $2^{\text {nd }}$ segment with a laterodorsal, large and conical sensorial appendix and one lateroventral spiniform seta adjacent to the $3^{\text {rd }}$ segment. $3^{\text {rd }}$ segment minuscule, situated latero-apically on the $2^{\text {nd }}$ segment, with 4 small stout setae at apex. Epipharynx (Figs.15, 21) formed by two retiary triangular plates, anteriorly clothed with fine and long setae and medially with shorter setae, with two orifices, probably gland openings, 

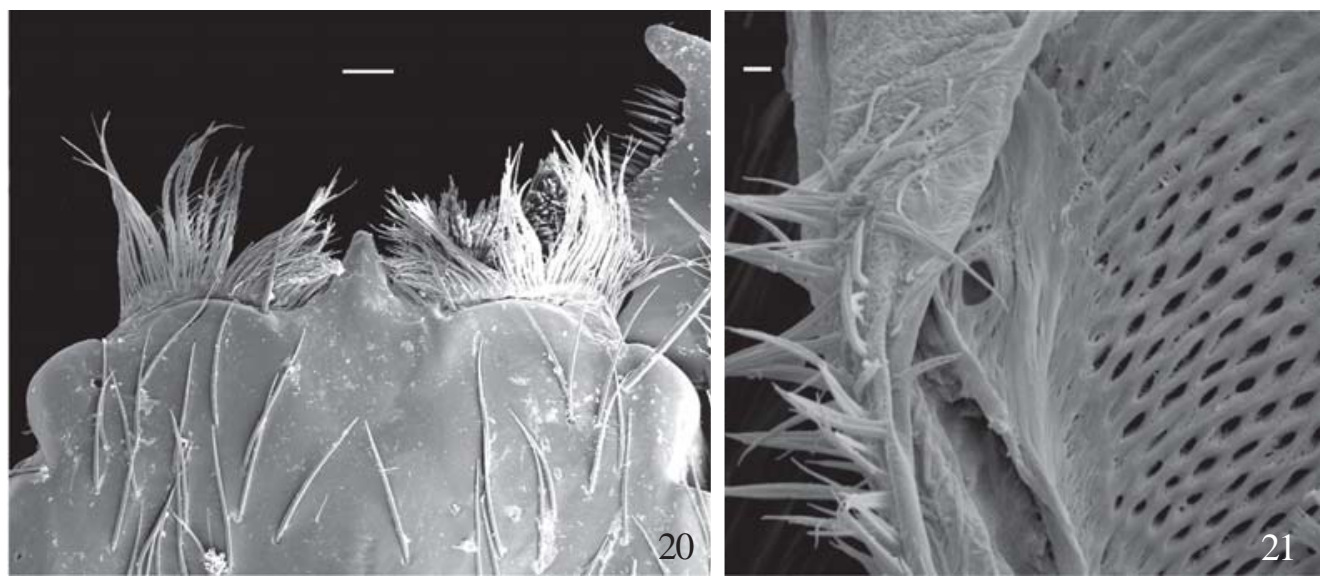

Figs. 20-21. Photuris fulvipes, larva. 20, nasale (dorsal); 21, detail of lateral margin of epipharynx showing one of the two orifices. Escales $=20$, $40 \mu \mathrm{m} ; 21,3 \mu \mathrm{m}$.

on each lateral margin and two groups of orifices between the plate bases. Hypopharynx (Fig.19) with anterior lobe densely hairy and bilobed at apex, base triangular, well sclerotized. Mandibles (Fig. 13) symmetrical, falcate, with a channel opening near at apex, densely hairy lateroventrally, dorsal side with elongate and stout setae; retinaculum and penicillus well developed. Maxillae and labium with reduced articulation, forming the hypostoma (Fig. 14); cardo subquadrate; stipes elongate with several fine and stout setae sparsely distributed and a dense setous tuft anteromesally; palpi 4-segmented, tapering to apex; galea palpiform, 2-segmented with one spiniform, elongate seta and several shorter setae; lacinia reduced, membranous and densely hairy. Labium (Fig.14). Prementum basally sclerotized, divided by a strongly sclerotized median septum, with 4 sparse and long setae anteriorly and 1 basal shorter seta, lateral margins with a setae tuft; postmentum partially sclerotized with several stout and fine long setae; palpi 2-segmented. Postgular area with 3 elongate, sclerotized areas and 4 stout, elongate setae transversally aligned.

Thorax (Figs. 5, 6). Pronotum semicircular with posterior margin slightly marginate, meso- and metanotum rectangular ( ca 3.5 times as wide as long). Mesepipleurum with a functional biforous spiracle situated in a circular salient area and adjacent to a small, black spot. Legs (Fig. 18) densely hairy with fine and short setae and variable size spiniform setae; tarsungulus strongly sclerotized with 1 setae in each side.

Abdomen (Figs. 5, 6) with 9 dorsally visible segments. Epipleura 1-8 with functional biforous spiracles (Fig. 12) situated in a salient circular area with a small black spot. Segments 1-8 with similar shape, gradually decreasing in size from 1 to $8.8^{\text {th }}$ segment with one pair of lateral luminous vesicles, hardly visible. $10^{\text {th }}$ segment (Fig. 6) posteroventrally directed with several tubular and protrusible filaments. $9^{\text {th }}$ tergum (Fig. 9) narrower than $8^{\text {th }}$, posteriorly rounded, with 3 pairs of elongate and stout setae on posterior margin and several shorter setae on posterolateral margins. $10^{\text {th }}$ tergum (Fig. 10) divided in 2 lateral, triangular and partially sclerotized areas with posterior margins clothed with several setae spatulated basally and frayed apicad. $9^{\text {th }}$ sternum (Fig. 11) weakly sclerotized, clothed with short setae and with some larger setae on lateral and posterior margins. $10^{\text {th }}$ sternum (Fig.11) weakly sclerotized, except for a transversal and strongly sclerotized band, with 2 ventral pairs of elongate setae and one lateral pair of elongate and stout setae.

Table II. Comparison of setal distribution between Photuris fulvipes and Bycellonycha sp. immatures.

\begin{tabular}{lll}
\hline & Photuris fulvipes & Bycellonycha sp. \\
\hline Larvae & 1 subfoliaceous seta & Several setae \\
Posterior angle of terga & 1 pair of setae & Several setae \\
Medioposteriorly abdominal terga & 1 longer, stouter seta & Equally fine, shorter setae \\
Abdominal epipleura & Dense spiniform setae & Sparse spiniform setae \\
Legs & & \\
Pupae & Glabrous & Setose \\
Dorsal head & Sparsely setose & Densely setose \\
Borders of pronotum & 1 pair & 2 pairs \\
Long setae on abdominal terga & Sparsely setose & Densely setose \\
Posterior angle of abdominal terga & & \\
\hline
\end{tabular}


Pupae (Figs. 7, 8). Total length $11.0 \mathrm{~mm}$, adecticous, exarate, cream-white. Pronotum semicircular, slightly marginate at apex, with anterior and lateral margins sparsely setose; posterior margin setose with a median pair of larger setae. Metanotum ca 2 times longer than mesonotum, both with a median pair of stout setae. Abdominal terga 1-8 with a few median setae, one pair distinctly longer and stouter; terga 1-9 with posterior angle prominent with several long, stout setae. Ventral abdominal surface with a few setae in the posterior angles of the ventrites $1-7,7^{\text {th }}$ ventrite indented at apex.

Examined material. BRAZIL. São Paulo, São Luiz do Paraitinga, São Pedro ranch, 03.XI.2000, S. P. Rosa \& M. Ladenthin coll.; 2 eggs, 3 first instar larvae, 3 sixth instar larvae, 2 pupae, 3 second instar exuviae, 2 thirth instar exuviae, 1 forth instar exuviae, 2 fifth instar exuviae, 2 sixth instar exuviae.

Taxonomic discussion. Photuris fulvipes larva is very similar to Photuris sp. illustrated by LaBella \& Lloyd (1991). Since this and other Photuris larvae are superficially described (Buschman, 1984) it is impossible to make a detailed comparison between species. Therefore, the immatures of $P$. fulvipes were compared to another resembling Brazilian Photurini, Bycellonycha sp. described by Costa et al. (1988), with which they are frequently confused. The larvae are similar in general appearance, differing by the spots on dorsum, which in Bycellonycha sp. are double in each segment. Moreover, both larvae and pupae of Bycellonycha sp. are more densely setose than P. fulvipes. The most significant differences in the setae are detailed in Table 2. Although it is premature to propose a precise immature diagnosis to the species or genera, these characteristics may have generic value. Further studies including others Photuris species will confirm or will not their specific value.
Acknowledgements. I am grateful to Ana Silvia Ferreira for corrections and suggestions, to Drs. Sergio Ide (Instituto Biológico, São Paulo) and Cleide Costa (MZSP) for critical reading, to Maria Jose S. Coelho (MZSP) for help in laboratory work, to Peterson L. Lopes (MZSP) for image digitalization, to Lara M. Guimarães (MZSP) for the electron micrograph images and to $\mathrm{CNPq}$ for grant.

\section{REFERENCES}

Barber, H. S. 1951. North American fireflies of the genus Photuris Smithsonian Miscellaneous Collection 117: 1-58.

Blackwelder, R. E. 1944. Checklist of the coleopterous insects of Mexico, Central America, the West Indies and South America. Part 2. Bulletin of United States National Museum 185: 280303.

Buschman, L. L. 1984. Larval biology and ecology of Photuris fireflies (Lampyridae: Coleoptera) in Northcentral Florida. Journal of the Kansas Entomological Society 57: 7-16.

Costa, C.; S. A. Vanin \& S. A. Casari-Chen. 1988. Larvas de Coleoptera do Brasil. São Paulo, Museu de Zoologia, Universidade de São Paulo, 282 p., 165 plates.

LaBella, D. B. \& J. E. Lloyd. 1991. Lampyridae (Cantharoidea). In: F. W. Stehr (ed.). Immature Insects v. 1. Dubuque, Kendall / Hunt Publishing Company, xvi +975 p.

Lawrence, J. F. (coord.).1991. Order Coleoptera, chap.34. In: F. W. Stehr (ed.). Immature Insects v. 2. Dubuque, Kendall / Hunt Publishing Company, xvi +975 p.

Lloyd, J. E. 1984. Occurrence of aggressive mimicry in fireflies. Florida Entomologist 67: 368-376.

McDermott, F. A. 1967. The North American fireflies of the genus Photuris Dejean. A modification of Barber's key (Coleoptera, Lampyridae). Coleopterists' Bulletin 21: 106-116.

Olivier, J. E. 1886. Études sur les lampyrides II. Annales de la Société Entomologique de France. serie 6, 6: 201-246.

Olivier, J. E. 1907. Coleoptera, Fam. Lampyridae. In: P. A. G. Wytsman (ed.). Genera Insectorum. Bruxelles, fasc. 53, p 1-74, plates. 1-3.

Viviani, V. 2001. Fireflies (Coleoptera: Lampyridae) from Southeastern Brazil: habitats, life history and bioluminescence. Annals of the Entomological Society of America 94: 129-145.

Zaragoza C. S. 1995. La familia Lampyridae (Coleoptera) en la Estación de Biología Tropical “Los Tuxtlas", Veracruz, México. Publicaciones Especiales del Instituto de Biología 14 Universidad Nacional Autónoma de México, México, 93 p. 